\title{
La condena de españoles a obrajes en Nueva España en 1721: su secuela en la provisión de oficios de las Audiencias indianas
}

\author{
Ascensión Baeza Martín
}

Departamento de Historia de América Universidad de Sevilla

En 1721 la Sala del Crimen de la Audiencia de México, compuesta en ese tiempo por un oidor de turno y dos alcaldes, los tres criollos, había condenado por robo a dos españoles y otros socios a una pena pecuniaria. Si no la cumplían se les llevaría a un obraje hasta satisfacer la sanción. La sentencia fue mal vista por los reos y por un grupo de españoles y criollos adinerados que se hicieron llamar "la nación española", los cuales se sintieron agraviados por considerarla inusitada y ser una puerta abierta para que en adelante se pudiera imponer dicha pena a los españoles.

Este suceso desencadenaría una serie de polémicas y tensiones entre el referido grupo y los ministros de la Sala, que daría como resultado una drástica resolución del monarca, cuyo solo rumor había causado ya la protesta de D. Juan Antonio de Ahumada, quien dirigió un alegato al monarca en favor de los criollos.

Una de las muchas sentencias dictadas por la Sala del Crimen de la Audiencia de México, que hubieran podido quedarse en un dato meramente circunstancial, sería el motor que sacó a la superficie otros espinosos asuntos que subyacían en el virreinato novohispano: la ya antigua rivalidad entre peninsulares y criollos, y la forma de provisión de los principales oficios de las Audiencias de Indias.

\section{La polémica sentencia de la Sala}

A través del oidor de turno D. Juan de Oliván Rebolledo ${ }^{1}$ y los alcaldes del Crimen D. Nicolás Chirinos Vandeval y D. Juan de la Veguellina²

1 Este oidor asistía en ese tiempo en la Sala del Crimen por no haber el número suficiente de ministros debido a la destitución de cuatro de ellos y del fiscal, y a que otro de los alcaldes, D. Francisco de Barbadillo Victoria, estaba en una comisión en el Nuevo Reino de León. El motivo de los ceses fueron los cargos que se les sacaron en la visita efectuada por D. Francisco de Garzarón a la Audiencia de México a partir de 1715. Archivo General de Indias, Sevilla (AGI, en adelante), Valero a S.M. México, 5 de abril de 1721. México, 488. Ver Alonso, M. a Luz: "La visita de Garzarón a la Audiencia de México: Notas para su estudio", en Estudios jurídicos en homenaje al maestro Guillermo Floris Margadant, México, 1988, pág. 23.

2 En otros documentos aparecen los apellidos de estos alcaldes con distinta grafía: Chirino o Vandesval, y Vequenilla o Velleguina. 
Sandoval, la Sala del Crimen había condenado en 1721, por indicios de haber resultado cómplices en un robo de dinero y géneros, a Matías Ruiz de Cossío y Ángel Díaz Terán, naturales de las montañas de Burgos, y a Francisco Flores y otros socios que decían ser también españoles, a pagar prorrateada la cantidad de mil pesos que era lo que importó el hurto. En caso de no contar con esa suma, se debería poner a los dos montañeses en un obraje y, una vez saldada la deuda, tendrían que salir desterrados cincuenta leguas en contorno de esa ciudad durante cinco años. Si no acataban esto, se les enviaría en última instancia a un presidio. Francisco Flores tendría que permanecer ocho años en un obraje para el mismo fin y después se le mantendría en una cárcel hasta su remisión a España. A otros implicados se les condenó a penas menores. ${ }^{3}$

D. Juan de la Veguellina Sandoval expresó haber sido de sentir contrario a la sentencia de los dos montañeses, porque lo que él pedía, y constaba en el libro secreto de la Audiencia donde se asentaban los votos, eran cinco años en presidio. No obstante, consideraba que se producían en ese Reino muchos hurtos, y que incluso habían llegado algunos delincuentes al extremo de llevarse los cálices dejando tiradas las sagradas formas, como ocurrió en Cholula, sin haberse podido averiguar quiénes habían sido los agresores. Por eso estimaba la conveniencia de medidas extraordinarias, aunque juzgaba que la de los reos a obrajes no lo era, ya que la Sala del Crimen había dado otras sentencias semejantes a ésta y no habían causado tanta novedad. ${ }^{4}$

Por real cédula de 18 de diciembre de $1722,{ }^{5}$ el monarca puso al corriente al recién llegado virrey D. Juan de Acuña y Bejarano, primer marqués de Casafuerte, ${ }^{6}$ de toda esta materia. En ella informaba Felipe V al nuevo mandatario de cómo su antecesor en el virreinato, el marqués de

3 AGI, México, 674. Sentencia de la Sala del Crimen. México, 6 de junio de 1721, en Testimonio de los autos que se han tratado contra D. Ángel Terán, D. Matías Ruiz de Cossío y otros. México, 15 de mayo de 1725, fols. 181-182v. En el artículo de Bouhrass Asmaá: "El reparto de los reos en los obrajes de Querétaro hacia 1740", en VII Congreso Internacional de Historia de América, Zaragoza, 1996, vol. 2, págs. 942-945, se hace un breve apunte sobre este episodio.

4 AGI, México, 673. D. Juan de la Veguellina a S.M. México, 9 de diciembre de 1721.

5 AGI, México, 565. Real cédula al virrey de Nueva España. Madrid, 18 de diciembre de 1722, en Testimonio n. ${ }^{\circ} 14$ de lo ejecutado en virtud de reales cédulas. México, 16 de octubre de 1723, fols.1-10. En ella resume el rey lo sucedido. Los diversos pasos de este expediente se encuentran en AGI, México, 673 y 674.

6 Estamos preparando nuestra tesis doctoral sobre este virrey que se hizo cargo del gobierno desde el 1 de octubre de 1722 hasta el 17 de marzo de 1734 en que falleció. Para conocer datos biográficos del mismo consultar Núñez y Domínguez, José de J.: Un virrey limeño en México, México, 1927. Rivera Cambas, Manuel: Los gobernantes de México, México, 1872, tomo I, págs. 326-339. 
Valero, le había dado cuenta con autos, en carta de 13 de diciembre de $1721,{ }^{7}$ de tal hecho y de la novedad que le había causado la sentencia. También de que Francisco Flores pidió que se revocara la misma, se le absolviese y diera por libre por los argumentos que alegó en su defensa, especialmente por ser español y por esta razón no debérsele imponer tal pena. Que Flores había declarado ser hijo natural del maese de campo D. José Muñoz de Estrada y haber nacido en las montañas de Burgos, pero que no había presentado información acreditativa alguna.

Por su parte, el querellante, Juan Basilio García, vecino y mercader de México, había mostrado una escritura donde constaba que Flores era en realidad esclavo de Muñoz de Estrada. En la misma se evidenciaba que Flores, "blanco, de pelo bermejo", había sido vendido a los nueve años de edad a aquél en Madrid en 1704 por D. Diego Terán y Monjaraz, caballero de la Orden de Calatrava y ayuda de Cámara del rey, en la cantidad de 20 doblones. El verdadero nombre del que se decía llamar Francisco Flores resultó ser Francisco de la Hoya y era turco, todo lo cual quedó confirmado al interrogarse a D. José Muñoz de Estrada y D. Jerónimo Muñoz, hijo y hermano respectivamente del citado maese de campo, ya difunto. ${ }^{8}$

Seguía refiriendo el rey a Casafuerte que posteriormente pidieron también Matías Ruiz de Cossío y Ángel Díaz Terán licencia para suplicar de dicha sentencia, la cual se les concedió, pero no se le dieron los autos por estar pendientes en varias diligencias. Presentaron entonces los afectados sus quejas al virrey Valero mediante un memorial en el que expresaron ser naturales de las montañas de Burgos y lo injurioso que había sido para su nación dicha sentencia. Alegaban que a los españoles que delinquían se les tenía señalados los presidios, y que las penas a obrajes estaban previstas por las leyes sólo para los indios, mulatos y otras castas. Por todo lo cual solicitaban del virrey que ordenara al escribano de la Sala del Crimen les diera testimonio de dichos autos para acudir con ellos al monarca. ${ }^{9}$

7 AGI, México, 673. Valero a S.M. México, 13 de diciembre de 1721. En esta representación refiere el virrey cómo Oliván Rebolledo le hizo creer que la sentencia a los españoles no era a obrajes, sino a que se pusieran en casa de algunos maestros de oficios. Según Valero, pudo comprobar por una relación que constaba en su Secretaría, que aquél le había engañado y la sentencia era substancialmente a obrajes, aunque no apareciera esa palabra en el texto. La Sala del Crimen a Valero. México, 22 de octubre de 1721. Ibídem.

8 AGI, México, 565. Real cédula al virrey de Nueva España. Madrid, 18 de diciembre de 1722. AGI, México, 673. Escritura. Villa de Madrid, 21 de noviembre de 1704, en Testimonio n. ${ }^{\circ} 1$ de los Autos criminales de querella de D. Juan Basilio García contra Matías Ruiz de Cossío y otros, fols. 132-135.

9 AGI, México, 565. Real cédula al virrey de Nueva España. Madrid, 18 de diciembre de 1722. 
Valero, con el parecer de su asesor, había ordenado que se le pasaran los autos, pero la Sala se resistió, con lo cual se pusieron de manifiesto las diferencias entre ambas autoridades por cuestiones de jurisdicción. Se apoyaron los de la Sala para esta negativa en la ley 35 , título $3 .^{\circ}$ y la ley 34 del libro 2. ${ }^{\circ}$, título 17 de la Recopilación de Indias, y en una Real Cédula de 30 de diciembre de 1694 en la que se mandaba al entonces virrey Conde de Galve que no estorbara ni se entrometiera en las causas que tocaran jurisdiccionalmente a la Sala.

A la vista de todo, el asesor de Valero había respondido que dicha ley 35 hacía referencia al conocimiento judicial, y que lo que en ella se ordenaba era que los virreyes no sacaran las causas de los tribunales a donde pertenecían y dejaran las primeras instancias a quien competiera por derecho. En cambio, no había prohibición alguna para que el virrey en calidad de presidente de la Audiencia pudiera mandar que se le diera cualquier auto a fin de documentarse e informar al monarca. Esto, en opinión del asesor, no se oponía a la jurisdicción de la Sala, que era lo que se prohibía por la ley 34 , título 17 , libro $2 .^{\circ}$, por todo lo cual debería el escribano de Cámara pasar los autos al virrey, bajo pena de mil pesos. ${ }^{10}$

Continuaba exponiendo el rey a Casafuerte cómo, a consecuencia de todas estas diligencias, se le dio a Matías Ruiz de Cossío y a su compañero testimonio de todos los autos. En estas circunstancias, había acudido D. Francisco de las Navedas con poder y representación de un grupo de españoles y criollos distinguidos, un total de 242 personas que se sintieron agraviadas por la mencionada condena y que se denominaron "la nación española", al visitador general D. Francisco de Garzarón. ${ }^{11}$ Le habían referido el estado en que se encontraba esta causa, el modo irregular con que se había procedido, lo injusto y denigrante que había sido para los españoles la sentencia dictada, y la afrenta que había causado esta novedad no sólo a sus paisanos, sino a todos los europeos y nacionales de esos reinos, que

10 AGI, México, 673. Ibídem. Respuesta del maestro Sáenz, asesor del virrey. México, 23 de octubre de 1721 .

11 D. Francisco de Garzarón era inquisidor del Tribunal de la Inquisición de México y había sido designado por el monarca para la visita a los Tribunales de Nueva España. AGI, Escribanía de Cámara, 278A. Real cédula al virrey Valero. Buen Retiro, 21 de diciembre de 1715 en Cuaderno $1 .^{\circ}$ de la Visita a la Audiencia de México, fols. 11v-4. Dan noticia de esta visita y de algunos de sus aspectos, entre otros: Priestley, Herbert Ingram: José de Gálvez, visitor general of New Spain (1765-1771), University of California Press. Berkeley, 1916, págs. 206 ss.; Burkholder Mark A. y D. S. Chandler: De la impotencia a la autoridad, México, 1984, págs. 62-63; y Gómez Gómez, Amalia: Visitas de la Real Hacienda novohispana en el reinado de Felipe V., Sevilla, 1979, pág. 196. Una visión más completa de esta visita nos la da Alonso: "La visita de Garzarón”, págs. 11-27. 
como españoles y descendientes de ellos merecían alguna deferencia y distinción en la imposición de las penas. Pretendieron también que la Sala exhibiera la sumaria que se hubiese hecho para informar al monarca. ${ }^{12}$

Garzarón se había abstenido de inmiscuirse en ese asunto por no ser de su incumbencia, por lo cual los querellantes acudirían al Real Acuerdo con el mismo poder y escrito, habiendo hecho constar también que el oidor D. Gerónimo de Soria Velázquez, marqués de Villahermosa de Alfaro, había estado efectuando pesquisas con idea de tacharlos de tumultuarios por defender su nación española. El referido oidor desmentiría lo que los representantes de "la nación española" habían dicho de su persona, y pediría que acreditaran lo que afirmaban. ${ }^{13}$

El fiscal pidió traslado de estos segundos autos como incidentes a los principales, pero la Audiencia declaró no haber lugar, ni tampoco al testimonio que de ellos pidieron ambas partes, habiendo considerado conveniente cerrar las puertas a semejantes instancias. ${ }^{14}$

Los demandantes habían nombrado también otros apoderados, residentes en Madrid, para que solicitaran del rey el desagravio de la referida sentencia de la Sala, cuya condena había causado tanto escándalo en México que los principales españoles la consideraron como causa propia. Estos apoderados eran: $\left.1^{\circ} .^{\circ}\right)$ D. Domingo Pérez de Celis; $2^{\circ}$ ) D. Antonio García de la Madrid; $3 .^{\circ}$ ) D. Dionisio de Arce y $4 .^{\circ}$ ) D. José de Leticia..$^{15}$

Mientras tanto, D. Francisco de las Navedas en nombre de "la nación española" había solicitado al virrey Valero que se le dieran testimonios de los reos españoles que en diferentes tiempos se hubieran condenado por la Sala del Crimen a obrajes. ${ }^{16}$ Una vez obtenidos, los querellantes pondrían una demanda contra los escribanos de Cámara, Alvarado Cantabrana y Ortega, por estimar que los testimonios que se les proporcionó no se ajustaban a la verdad, y porque el tasador Gudiel le había cobrado por ellos un precio excesivo.

12 AGI, México, 565. Real cédula al virrey de Nueva España. Madrid, 18 de diciembre de 1722. Memorial de D. Francisco de las Navedas a Garzarón. México, 7 de noviembre de 1721. AGI, México, 673.

13 AGI, México, 673. Decreto de Garzarón. México, 8 de noviembre de 1721. La Sala del Crimen a S.M. México, 10 de diciembre de 1721.

14 Ibídem.

15 AGI, México, 673. Certificación de D. Jacobo Gómez de Paradela, 29 octubre de 1721. Memorial de D. Domingo Pérez de Celis a S.M. (Sin fecha).

16 AGI, México, 673. Decreto del virrey Valero. México, 20 de noviembre de 1721. Certificación de D. Juan de Alvarado Cantabrana, en Testimonio de la certificación dada de mandato de Valero. México, 5 de diciembre de 1721, fols. 1v-13v. Certificación de D. Luis de Ortega, en Testimonio de varios reos españoles a obrajes desde 1689 a 1721. México, 10 de diciembre de 1721, fols. 4-13. 
En opinión de "la nación española", los escribanos de la Sala del Crimen D. Juan de Alvarado Cantabrana y D. Luis de Ortega habían dado los testimonios falsos sobre los ejemplares de españoles a obrajes forzados por Oliván Rebolledo, quien borró y añadió lo que le pareció en una minuta presentada por Cantabrana encargándole que, conforme a esas notas, debía de redactar los testimonios. Según los querellantes, el escribano tuvo que acatar los designios del oidor por miedo, ya que era su superior y tenía un carácter muy dominante. Acusaban también a Oliván de que solía recibir regalos del demandante D. Juan Basilio García, en ésta y en otras causas, por medio de su cajero D. Miguel Terán. ${ }^{17}$

Este incidente fue seguido por el visitador general D. Francisco de Garzarón, el cual impuso las siguientes condenas: a Cantabrana se le privó de su oficio a perpetuidad, se le desterró de México y diez leguas alrededor durante cuatro años; a Ortega se le suspendió por diez años en el uso y ejercicio de sus empleos de escribano, receptor y teniente de escribano y a dos años de destierro en las mismas condiciones que el anterior; a Gudiel, a la suspensión durante seis meses en el uso y ejercicio de su oficio de tasador, y se le ordenó hacer de nuevo la tasación que anteriormente había efectuado en mil pesos y que se consideró excesiva. Todos tenían que abonar además las costas. ${ }^{18}$

En España también había causado revuelo la condena de Cossío y Terán, concretamente entre sus paisanos. Los representantes del cabildo de la ciudad de Burgos escribirían un memorial al rey en el que le recordaban su antigüedad e inveterado esplendor, así como el lustre y el honor de sus hijos. Le expresaban el agravio que se les había ocasionado por la venta de los dos montañeses como esclavos a obrajes, y esperaban que no quedara impune esta novedad. En su opinión, esta sentencia iba contra todas las leyes naturales, ya que entre católicos ni se permitía ni se practicaba semejante crueldad. ${ }^{19}$

\section{Ambigüedad de la condena}

A manos del Consejo habían llegado todos los informes de este asunto remitidos por la Audiencia y Sala del Crimen de México y los memoriales de D. Domingo Pérez de Celis. Este sujeto, como ya hemos dicho, en nombre de sus representados, se lamentaba al monarca de la irregularidad de la

17 AGI, México, 673 y 674. Memoriales de D. Domingo Pérez de Celis a S.M. (Sin fecha).

18 AGI, México, 674. Sentencia de Garzarón. México, 22 de septiembre de 1722, en Testimonio n. ${ }^{\circ} 16$ de los Autos hechos a pedimento de la nación española contra los escribanos de Cámara. México, 9 de noviembre de 1723, fols. 252v-253v.

19 AGI, México, 673. La Ciudad de Burgos a S.M. Burgos, 19 de junio de 1722. 
sentencia que habían dado Oliván, Chirinos y de la Veguellina, los tres criollos, contra los españoles; de la falsedad de los testimonios y el excesivo precio que les cobró el tasador D. Juan Arias Gudiel por unos instrumentos que servían para injuriar a los mismos que los pagaron. Aseguraba que muchos reos decían ser españoles para librarse de dicha pena, y que éstas se conmutaban siempre que lo fueran. Según ellos, el empeño de la Sala del Crimen era introducir y establecer con esa sentencia el que los españoles pudieran ser condenados a obrajes. En los memoriales se afirmaba que por regla general los criollos miraban con desprecio y odio a los españoles y, si tenían algún poder, se valían de él encubriéndolo con el nombre de justicia. ${ }^{20}$

El fiscal del Consejo había observado la contradicción de los testimonios presentados en orden a si habían sido o no condenados españoles a obrajes. En estas circunstancias y no pudiéndose dar providencia correspondiente a la pena del delito del que hubiere faltado a la verdad, el monarca expresaría al virrey Casafuerte que se le remitirían todos los autos que hubiera en el Consejo sobre esta materia para que, con los ministros de su satisfacción, se hicieran las comprobaciones pertinentes. Le prevenía el rey a Casafuerte de que los ministros que nombrara fueran "desapasionados, legales y temerosos", y que no se hubieran visto mezclados en esa causa. También le ordenaba que llamara a su presencia a uno o dos de los principales sujetos que hubieran solicitado el poder y les advirtiera cuán de su desagrado había sido su participación en materia tan ruidosa. ${ }^{21}$

Casafuerte designó para esta comisión a D. José Gutiérrez de la Peña y a D. Gregorio Carrillo, ambos oidores de la Audiencia de México, porque sabía que cuando ocurrió el suceso estaban en Guatemala y no se habían mezclado directa ni indirectamente en esta causa. Enterado el virrey de que los principales en solicitar el poder habían sido D. Juan Rubín de Celis y D. Pedro de Escorza, los hizo comparecer ante su presencia y los amonestó como el monarca le había encargado. ${ }^{22}$

Los oidores Gutiérrez de la Peña y Carrillo mandaron exhibir los libros de los obrajeros actuales y antiguos donde se registraban todos los condenados al servicio personal en sus obrajes, y de los 403 testimonios sacados de las ciudades de México y Querétaro, no se halló ningún español, igualmente pasó en otros obrajes investigados. Aparte, recibieron 30 declaraciones juradas de los dueños de obrajes de la jurisdicción de Guchiapa,

20 AGI, México, 673 y 674. Memoriales de D. Domingo Pérez de Celis a S.M. (Sin fecha).

21 AGI, México, 565. Real Cédula al virrey de Nueva España. Madrid, 18 de diciembre de 1722.

22 AGI, México, 1330. Casafuerte a S.M. México, 10 de noviembre de 1723. 
Celaya y Villa de San Miguel el Grande, donde se constató que nunca hubo españoles condenados a ese servicio, ni se había escuchado a los vecinos de más edad aseverar tal cosa. Ambos oidores dictaminarían entonces que los escribanos faltaron a la verdad, porque, debiendo certificar las ventas practicadas en obrajes, mezclaron éstas confusamente con condenaciones a presidios y otras. ${ }^{23}$

¿Se habían condenado o no antes de este suceso a los españoles a obrajes? El asunto se nos muestra turbio, a pesar de que los oidores comisionados por Casafuerte parecen probar que no se aplicó esa condena. Con independencia de si hubo fraude en los testimonios elaborados por los escribanos, la Sala del Crimen había expuesto al rey unos razonamientos bastante convincentes. Aseguraban que esa sentencia a españoles no era nueva, sino que estaba contenida en las Leyes de Indias, en donde únicamente se exceptuaba de la misma a los indios, y en cuanto a las de Castilla, se mandaba condenar a los españoles a servir y poner a oficios. ${ }^{24}$ Según los de la Sala del Crimen esa sentencia se había aplicado de 30 años a esa parte por el virrey, y por noticias que tenían, casi desde que se conquistó América, y no sólo a negros, mulatos y mestizos, sino a españoles. A su parecer, era legal que "el que no tiene con qué pagar en la pecunia, pague con el cuerpo", y que no había orden en contrario que la prohibiera. ${ }^{25}$

Argumentaban los de la Sala al rey que la pena impuesta a esos españoles no había sido por su calidad de españoles, sino de delincuentes, y que lo que se hacía no era venderlos a obrajes, sino a que obtuvieran con su trabajo en oficinas y oficios la cantidad en la que habían sido condenados por su delito. Añadían que el oficio de tejer y otros que existían en los obrajes ni en América ni en España se tenían por infames, porque entonces ninguno querría aprenderlo ni ejercerlo, como lo hacían los españoles en Segovia, Chinchilla, Navas y otras partes de España. ${ }^{26}$

23 AGI, México, 674. Casafuerte a S.M. México, 6 de mayo de 1724. Acompaña una certificación de los dos oidores, de 4 de mayo de ese año. Memorial de D. Domingo Pérez de Celis a S.M. (Sin fecha).

24 AGI, México, 673. La Sala del Crimen a S.M. México, 10 de diciembre de 1721.

25 Ibídem. García Acosta, Virginia: "Oscilación de los precios y de la producción en el México borbónico: el trigo y el pan" en Arij Ouweneel y Cristina Torales (comp.): Empresarios, indios y estado. Perfil de la economía mexicana (siglo XVIII), 1988, pág. 119. Se expresa que la Real Sala del Crimen enviaba reos a las panaderías para que cumpliesen su condena como operarios, y se compara la diferencia de criterio de los dueños de las panaderías en los siglos XVI y XVIII. En el primer caso eran bien aceptados los reos, pero en el Siglo Ilustrado ya no lo eran tanto. Para una visión más reciente de este tema consultar Bouhrass: "El reparto de reos...", págs. 939-985.

26 AGI, México, 673. La Sala del Crimen a S.M. México, 3 de noviembre y 10 de diciembre de 1721 . 
Ponían los de la Sala ejemplos de que en los obrajes de San Miguel el Grande, Acambaro, Istla, Jalpa, Texcoco y en los de Querétaro había españoles, criollos y gachupines. Unos eran administradores y cobraban 600 pesos anuales; otros mayordomos, con 500 pesos, por lo general, al año, y tanto éstos como los administradores era necesario que tuvieran experiencia y conocimiento de lo que se fabricaba, pues de ello dependía la ganancia o pérdida de los amos; ayudantes, que eran los que pesaban las lanas cuando se daban los tequios a los operarios, 300 pesos; porteros, 10 ó 12 pesos al mes además de la ración semanal de carne, maíz y chile; tejedores y tintoreros, que ganaban según lo que trabajaban. También había operarios indios, mulatos, etcétera, dedicados a cardar e hilar. ${ }^{27}$

Afirmaban los ministros que lo que había hecho la Sala no era más que obedecer la ley $1 .^{\mathrm{a}}$ y $2 .^{\mathrm{a}}$, título $4 .^{\mathrm{o}}$ de la citada Recopilación, en la que se prevenía que a los vagabundos españoles, mestizos, mulatos y zambaigos les castigaran las justicias sus excesos con todo rigor, obligando a los que fuesen oficiales a que trabajaran en sus oficios, y a los que no lo fueren a que aprendieran en qué ejercitarse o se pusieran a servir. Para ellos, tanto mulatos como españoles eran iguales en el delito y en el ocio. ${ }^{28}$

D. Juan de Ortega, uno de los escribanos que había dado los testimonios sobre la condena de españoles a obrajes, aseveraba que era muy difícil saber si los reos eran o no españoles, porque para ello era necesario conocerlos desde la cuna con toda su ascendencia. En cuanto a juzgarlo por los colores era muy peligroso, porque había muchos mulatos, mestizos y coyotes más blancos que muchos españoles, y al contrario, españoles más prietos que muchos mulatos..$^{29}$

La iglesia metropolitana de México coincidía con lo expresado por la Sala del Crimen, asegurando que a los prudentes no les había causado novedad la sentencia porque era conforme a las leyes reales, y se había visto ejecutar en otros de la misma calidad que los montañeses. ${ }^{30}$

El provincial y religiosos de la Orden de la Merced aseveraban que la queja de los montañeses y sus paisanos ni era justa ni tenía por qué causar

27 AGI, México, 673. Declaración de varios testigos. México, 27 y 30 de octubre de 1721 y Certificación de D. Juan de Alvarado Cantabrana. México, 29 de octubre de 1721, en Testimonio n. ${ }^{\circ} 17$ de la averiguación de la Sala del Crimen. México, 30 de octubre de 1721. de 1721 .

28 AGI, México, 673. La Sala del Crimen a S.M. México, 3 de noviembre y 10 de diciembre

29 AGI, México, 674. Petición de D. Luis de Ortega. (Sin fecha).

30 AGI, México, 531. La Iglesia metropolitana de México a S.M. México, 23 de agosto de 1726. Los firmantes eran D. Antonio de Villar y Monroy, M. Tomás Montañés, Luis Andrés de Torres y Francisco Rodríguez Navarijo. 
conmoción o alteración, pues no había pueblo que tuviera privilegio para robar ni para que se les dejara en la esfera de nobles, que en este caso no lo eran, después de demostrada su culpabilidad. Estimaban que la justicia no consistía sólo en castigar al reo, sino en procurar que la parte quedara satisfecha. Consideraban que la pena a obrajes tenía tan poco de afrenta que en todos los obrajes del Reino había muchos blancos de Europa y América, que se empleaban en esa labor para mantener a sus familias, sin que ese trabajo les deshonrase. ${ }^{31}$

Otro ejemplo de que sí parecen haber sido condenados españoles a obrajes nos lo da el que fuera apoderado de D. Juan de Oliván en Madrid, D. Juan Antonio de Ahumada, más conocido luego por su alegato en favor de los criollos. Aseveraba Ahumada que, cuando entró a servir Oliván el turno de alcalde de Corte, estaba Nueva España infestada de ladrones, y deduciéndose que de los vagabundos y holgazanes podrían surgir delincuentes, se dieron distintas providencias para su extirpación, entre ellas la de que se condenaran a obrajes. Hacía referencia también el apoderado de que presentaba testimonio de una real cédula de 15 de marzo de 1639, en la que constaba que no sólo a los indios se condenaba a obrajes, sino a los españoles, con lo cual quería demostrar que dicha pena era ya una práctica antigua y no una novedad de los actuales componentes de la Sala del Crimen. ${ }^{32}$

En la referida real cédula presentada por Ahumada se citaban otras. Entre ellas, una de 3 de junio de 1555 en la que se ordenaba que tan sólo las Audiencias pudieran mandar a obrajes a los indios por tiempo limitado, y eso se practicó en la de México. Sin embargo, a través de las visitas a estos centros pudieron comprobar los ministros el desorden que había al respecto, pues no sólo a los indios que habían sido condenados a obrajes por un determinado tiempo los mantenían perpetuamente en ellos, sino también a muchos españoles, quienes estando allí por diferentes causas y sin oportunidad de reclamar, se quedaban como esclavos. Por otra real cédula de 27 de enero de 1632 se prohibió poner a los indios en obrajes. En 1639 el monarca dejó al criterio del virrey y de los ministros togados de la Audiencia el castigar los delitos graves de los indios para ejemplo público y respeto a la justicia, usando con ellos de "equidad y misericordia", pero no se decía nada acerca de los españoles. ${ }^{33}$

31 AGI, México, 531. El provincial y religiosos de la Merced a S.M. México, 20 de agosto de 1726. Ibídem. El provincial era D. Agustín de los Reyes Rivera y Mellado.

32 AGI, México, 674. Memorial de D. Juan Antonio de Ahumada a S.M. (Sin fecha).

33 AGI, México, 674. Real cédula a los alcaldes del Crimen de la Audiencia de México. Madrid, 15 de marzo de 1639. 
En este tiempo que abarcó el asunto de la condena de los dos montañeses a obrajes, se había ofrecido también la duda a la Sala del Crimen de si se podían condenar a los indios a obrajes de particulares, pues existían leyes y autos acordados que se contradecían. ${ }^{34}$ El fiscal del Consejo aclararía que una cosa era que a los indios se les diera un buen tratamiento y se obviaran todos los abusos que se cometían con ellos, como se había dispuesto últimamente por real cédula de 13 de diciembre de $1721,{ }^{35}$ a raíz de la visita de Garzarón, y otra el que cumplieran la pena correspondiente al delito cometido. Era de parecer el fiscal —y así lo aprobó el Consejo- que todas las veces que el delito lo requiriera se les podría poner dicha pena, pues de lo contrario, al no poderse practicar en esos parajes las de galeras ni otras, se quedarían sin castigo. ${ }^{36}$

En contrapartida a todas estas opiniones y argumentaciones, el Real Acuerdo de la Audiencia de México manifestó que se había tenido por extraña e injuriosa la condena de los dos montañeses a obrajes. Consideraban que si en éstos se encontraban algunos españoles era voluntariamente por su salario o alguna gratificación, y afirmaban que el mantenimiento más seguro de esos dominios descansaba principalmente en la reputación de los españoles y particularmente de los europeos. ${ }^{37}$

También "la nación española", basándose esta vez en lo que había afirmado D. Antonio Vélez Escalante, mayordomo del obraje de D. Nicolás García de la Mora, expresaba que, aunque a algunos muchachos españoles se les solía poner a que aprendieran oficios con que en adelante pudieran sustentarse, no se les había obligado a ello como reos en fuerza de sentencias y condenaciones. ${ }^{38}$

Al entonces fiscal del Consejo, D. Tomás de Sola, a pesar de que aseveraba que "como opuesto a la nobleza española, jamás se había practicado la condena a obrajes", no le pareció desacertada la sentencia de la Sala del Crimen, y por lo tanto, no la consideró ignominiosa. Argumentaba el fiscal, citando a jurisconsultos y teólogos, que aunque el noble no pudiera

34 AGI, México, 528. La Sala del Crimen a S.M. México, 18 de marzo de 1723.

35 Ibídem. Real cédula al presidente y Audiencia de México. Lerma, 13 de diciembre de 1721.

36 Ibídem. Respuesta del fiscal del Consejo. Madrid, 27 de octubre de 1723. Consejo, 30 de octubre de 1723 .

37 AGI, México, 673. El Real Acuerdo a S.M. México, 13 de diciembre de 1721. Este Acuerdo estaba compuesto por el virrey Valero y los oidores D. José Joaquín de Uribe, D. Juan Picado Pacheco (españoles) y D. Diego Antonio de Oviedo y Baños (criollo). Para más datos sobre la biografía de estos ministros véase Burkholder, Mark A. y D. S. Chandler: Biographical Dictionary of Audiencia Ministers in the Americas, 1687-1821, London, 1982, págs. 249, 262 y 333-334.

38 AGI, México, 673. Memorial de D. Domingo Pérez de Celis. (Sin fecha). 
ser condenado a galeras para que remase como galeote, sí podía servir en ellas como soldado, sin sueldo, porque en eso no se le irrogaba afrenta alguna, ya que ésta nacía del puesto o función que se le diera. Añadía que muchas veces solían condenar los jueces reales a los ladrones a galeras para que, con el importe del estipendio que ganaban, pudieran mantenerse y pagar la cantidad hurtada, y que no por eso dichos reos tenían la consideración de esclavos ni vendidos. ${ }^{39}$

Aludiendo a la condena impuesta por la Sala del Crimen de México decía el fiscal del Consejo que, aunque se dijera que esa pena no se había practicado jamás con los españoles, lo que no se podía dudar es que estaba en uso y que, por lo tanto, no debía haber excepción de personas si el delito cometido por éstas así lo requiriese. Apoyándose en las Doce Tablas, la Ley Petilia, la Recopilación de Castilla y otras leyes, ponía de manifiesto el fiscal que los de la Sala del Crimen habían tenido motivos para la sentencia que dieron y que sus procedimientos no eran merecedores de las ásperas críticas que habían recibido. ${ }^{40}$

El fiscal del Consejo era de la opinión de que la referida pena a obrajes pudiera mandarse de ahí en adelante, porque estaba comprobado que por las penas regulares no se acababan de extinguir los frecuentes hurtos que se producían en ese Reino. Estimaba que si dicha pena había sido tan sensible, podría ser el remedio más eficaz para que cesaran los robos y saqueos. Al final, y a pesar de todos sus anteriores argumentos, estimó el fiscal como más a propósito prevenir a los alcaldes del Crimen de México para que, en el caso presente y otros que pudieran ofrecerse, excusaran este tipo de condenaciones, como no observadas ni practicadas en Indias, y se aplicaran las más rígidas y usuales contenidas en la leyes. ${ }^{41}$

\section{Resoluciones de la Corona}

El monarca, teniendo presente la gravedad de los incidentes que habían rodeado a esta causa y la conmoción que se originó en México, mandó que el Consejo tomara en sí el conocimiento de la misma, dispensando que la Sala del Crimen lo hiciera en vista y revista como estaba dispuesto por las leyes. A la Audiencia le ordenó que liberase de la referida

39 AGI, México, 673. Respuesta del fiscal del Consejo. Madrid, 1 de julio de 1722.

40 Ibídem.

41 Ibídem. 
pena a Cossío y Terán, y que se guardara la costumbre y estilo practicado en aquellas Provincias en cuanto a no imponer la pena de obrajes a los legítimos españoles y sus descendientes. ${ }^{42}$

El Consejo de Indias, por su parte, había hecho presente al rey las inquietudes que D. Juan de Oliván había originado en esta causa, y las que se podrían derivar manteniéndose en México con dicha plaza, máxime siendo natural de ese reino y con parientes en la misma, lo que, según se manifestaba, le servía para mezclarse en ese y otros negocios.

Para los del Consejo, el hecho de que los jueces fueran naturales de la misma ciudad y provincia en donde ejercían sus empleos —y más estando tan distantes del monarca - era algo perjudicial y dañoso, como ya lo había demostrado la experiencia. Por ello sugerían la conveniencia de separar a Oliván de la Audiencia de México y trasladarlo a la de Lima o ponerlo por vía de depósito en la de Guatemala. De momento el rey no resolvió sobre este asunto, por haberse recibido unos memoriales del oidor Oliván Rebolledo en su defensa. ${ }^{43}$

Representaba a Oliván en Madrid, como ya hemos referido, el abogado de la Audiencia de México, D. Juan Antonio de Ahumada. Presentó el apoderado testimonios de los servicios prestados por Oliván en pro de la Corona, y de entre los argumentos que exponía entresacamos el que afirma que este ministro no tenía odio a los españoles como habían alegado los de "la nación española", porque no era posible que un español, como lo eran también los americanos, aborreciese a los de su misma nación, de quienes descendía.

Hacía patente Ahumada al monarca que el amor que Oliván tenía a los españoles, y especialmente a los europeos, estaba acreditado por sus obras y ponía el ejemplo de la reparación, a sus instancias, del hospital de Perote, destinado únicamente para albergar a los españoles que pasaban a ese Reino sin medios hasta que los adquiriesen. También las diligencias efectuadas por Oliván siendo juez de bienes de difuntos a fin de que éstos llegaran a manos de sus parientes, cosa que no habían hecho muchos ministros europeos. Según Ahumada, toda la acusación contra Oliván había nacido de su recto proceder y del encono de los que se decían "la nación española", por haber defendido la justicia íntegramente y no permitir los detrimentos que habían intentado aquéllos contra el Real Erario y la administración de justicia. ${ }^{44}$

42 AGI, México, 674. Real cédula a Casafuerte y a la Audiencia de México. San Ildefonso, 21 de septiembre de 1726 .

43 Ibídem. Consejo de Indias a S.M. Madrid, 31 de octubre de 1726.

44 AGI, México, 674. Memorial de D. Juan Antonio de Ahumada a S.M. (Sin fecha). 
El Consejo estimó que, aunque estos testimonios de Ahumada no se habían tenido presentes al tiempo que se vio la causa de los montañeses, no repercutían en el proceso principal, porque lo que hacían era dar cuenta de los servicios prestados por Oliván en cumplimiento de su obligación. Por lo tanto, el dictamen del Consejo fue el mismo de antes.

Recordaban los del Consejo al monarca cómo, hallándose éste informado de los graves perjuicios que causaban las dispensaciones de las leyes que prohibían que, a los naturales de las provincias del Perú y Nueva España donde había tribunales, se les concedieran plazas de la administración de justicia en ellas y licencias para casarse con naturales de la misma tierra, había ordenado por real decreto de 31 de marzo de 1720 que en adelante se observara inviolablemente lo dispuesto por las leyes en relación a estos dos puntos. ${ }^{45}$

Al tener noticias en México del destino que se le quería dar a Oliván, le escribirían al rey algunas personas en su favor. Le hacían presente su calidad humana y su sapiencia en el ejercicio de su ministerio. Añadían que aunque Oliván era natural de aquel Reino, tenía escasos parientes y todos ellos distantes, unos en Guatemala, otros en Zacatecas y Michoacán y algunos en la corte. Aseguraban que, aunque todos estuvieren en México, necesitarían muy poco de su favor porque gozaban de una elevada posición económica. ${ }^{46}$ Harían ver al monarca que estaba mal informado de que había muchos oidores en México naturales de esa Corte, porque sólo estaba Oliván, que era de las Amilpas. Los otros tres criollos que había, uno era de Puebla, otro de la provincia de Michoacán y el tercero de La Habana, ${ }^{47}$ y expresaban que más inmediación tenían en Europa Aragón, Cataluña, Toledo y Sevilla y ni paisanos podían decirse, más aún, ni de un mismo reino. Seguían diciendo los religiosos que era lamentable que cualquier persona, perdiéndole el respeto al rey y confiados en que por la lejanía nunca se iba a averiguar la verdad, podía informarle falsamente sin que recibiera el debido castigo. ${ }^{48}$

45 AGI, México, 673. D. Francisco de Arana a D. Andrés de Elcorobarrutia. Madrid, 3 de abril de 1720. Le manda el primero al segundo una copia del referido decreto, que recoge Muro Orejón, Antonio: Cedulario Americano del siglo XVIII, Sevilla, 1969, tomo II, págs. 572-573.

46 AGI, México, 531. El provincial y religiosos de la Merced a S.M. México, 20 de agosto de 1726.

47 Ibídem. Aluden los religiosos primero a D. Juan de la Veguellina Sandoval que, aunque nació en México, su familia era oriunda de Puebla; en segundo lugar a D. Gerónimo de Soria Velázquez, natural de Pátzcuaro (Michoacán), y en tercero a D. Nicolás Chirinos Vandeval, nacido en La Habana. Burkholder y Chandler: Biographical Dictionary, págs. 97, 323-324 y 349-350.

48 AGI, México, 531. El provincial y religiosos de la Merced a S.M. México, 20 de agosto de 1726. 


\section{El clamor de los criollos: la apología de Ahumada}

Es en este momento del asunto de la condena de los españoles a obrajes cuando, según parece, a D. Juan Antonio de Ahumada, el apoderado de D. Juan de Oliván, le habían llegado rumores sobre una resolución del monarca que afectaba a los criollos. A raíz de ello, hacia 1725, escribió a Felipe $\mathrm{V}$ un alegato en favor de los mismos. ${ }^{49}$

Empezaba Ahumada en su escrito haciendo alusión al referido rumor: "En días pasados se derramó voz de que V.M. había mandado no se le consultase para empleo político o militar de la América a ninguno de los españoles que nacen en Indias". ${ }^{50}$ Ahumada dividía su manifiesto en cuatro puntos en los que, haciéndonos eco de la opinión de López Cámara, demostraba su erudición y retórica ${ }^{51}$ y su dominio de las fuentes del Derecho en sus diversas ramas, que hacían llevar hábilmente el asunto hacia unos objetivos muy concretos, no en vano se había formado en el colegio de Todos los Santos de México y en su Universidad. ${ }^{52}$ Estas cuestiones eran: 1) El derecho que asistía a los criollos para obtener los empleos de América. 2) Su idoneidad para optar a ellos. 3) La exclusividad de los criollos para obtener esos puestos. 4) Consecuencias que podrían derivarse de no dárseles todas las plazas. ${ }^{53}$ Ahumada emitía en su manifiesto juicios como éste:

"Si S.M. es nuestro legítimo Rey, nuestro adorado Dueño, tan benéfico con todos sus vasallos, ¿por qué los infelices de Indias han de privarse de recibir sus honores y han de querer los émulos que los impere no como su legítimo Señor sino como Tirano?" ${ }_{54}$

49 Juan Antonio de Ahumada: Representación político-legal, Madrid, 1925. Biblioteca Nacional de Madrid (BNM, en adelante), ms. 19124, fols. 306-326. Dio a conocer e hizo un análisis de este alegato López Cámara, Francisco: La génesis de la conciencia liberal en México, México, 1954. Hay una edición más reciente $\left(4 .^{\mathrm{a}}\right)$, de 1988 . Aunque no cita las fuentes, parece ser una copia distinta a la que se conserva en la Biblioteca Nacional de Madrid. Hace referencia al valor documental de este hallazgo Olmedo, Mauro: El desarrollo de la sociedad mexicana, Madrid, 1969, tomo II, págs. 236237. Brading, David: Orbe indiano. De la monarquía católica a la república criolla, 1492-1867, México, 1993, págs. 413-414, nota 41, cita el manifiesto de Ahumada tomado de la Biblioteca Nacional de México, manuscrito 1187.

50 Ahumada: Representación político-legal..., pág. 306.

51 López Cámara: La génesis de la conciencia liberal..., pág. 46.

52 Beristaín de Souza, José Mariano: Biblioteca Hispanoamericana Septentrional, México, 1980, vol. 1, pág. 33. López Cámara: La génesis de la conciencia liberal..., pág. 297, en donde cita al autor anterior.

53 Ahumada: Representación político legal..., fols. 306v, 310v, 312v y 317

54 Ibídem, fol. 325. 
Sin embargo, el discurso jurídico e histórico-filosófico utilizado por Ahumada ni era original ni añadía nada nuevo, sino muy similar al que habían hecho otros anteriormente, tal y como un joven abogado de Cartagena de Indias llamado Pedro de Bolívar y de la Redonda en 1667 y, más tempranamente aún, Solórzano y Velasco en 1652 y Ortiz de Cervantes en 1620.55

$\mathrm{El}$ antagonismo entre peninsulares y criollos, que reflejaba Ahumada en su manifiesto, es obvio que no era algo reciente, sino que venía de mucho tiempo atrás y se mantendría durante toda la etapa colonial, perviviendo aún después del establecimiento del nuevo Orden como asunto de roce social.

Tampoco era nuevo el concepto que tenían españoles y europeos acerca de la inferioridad de los criollos o de su incapacidad. Ya en 1618, un predicador jesuita proclamaba desde el púlpito en la capital mexicana que "los criollos en general no servían para nada bueno y que no eran capaces de regir ni un gallinero", con lo cual se originó un gran escándalo. ${ }^{56}$

El mismo virrey Linares, que gobernó en Nueva España desde 1711 a $1716,{ }^{57}$ decía que la mayoría de los criollos procedían de mulatos y negros y en el mejor de los casos de un indio. En su opinión, los criollos sentían antipatía hacia los europeos, pues "aun dándoles de barato los padres que ellos se quisieran apropiar, prorrumpen comúnmente que si supieran dónde tienen la sangre de gachupín se la sacaran y derramaran". Los calificaba de tener costumbres ociosas y unos espíritus apocados que los incitaban únicamente al vicio. ${ }^{58}$

Sería Linares partidario de que se apartara a los ministros criollos que había en la Audiencia de México dándole puestos eclesiásticos, como algunos de ellos mismos lo habían pedido, o trasladándolos a otras Audiencias. ${ }^{59}$ Es significativo que poco después se efectuara la visita de Garzarón, mediante la cual fueron destituidos muchos ministros, la mayoría naturales de esos reinos.

55 Burkholder y Chandler: De la impotencia a la autoridad..., pág. 21; nota 11 en donde afirma que el razonamiento de Pedro de Bolívar ya había sido utilizado por otros desde 1720 y cita a Lohmann Villena, Guillermo: Los ministros de la Audiencia de Lima en el reinado de los Borbones (1700-1821) Sevilla, 1974, pág. XXX y a J. I. Israel: Race, Class and Politics in Colonial México 16101670. Londres, 1975, pág. 83. Brading: Orbe indiano..., págs. 323-344.

56 Céspedes del Castillo, Guillermo: “América Hispánica (1492-1898)” en Tuñón de Lara, Manuel: Historia de España. Barcelona, 1988, tomo VI, págs. 283-284. Sobre esta idea, López Cámara: La génesis de la conciencia liberal..., págs. 23-28; y Brading: Orbe indiano..., págs. 328-329, en que aparecen opiniones encontradas respecto al carácter e inteligencia de los criollos.

57 García Purón, Manuel: México y sus gobernantes (Biografías), México, 1964, págs. 107-108.

58 Memoria del virrey Linares. BNM, ms. 2929, fols. 75-75v. Una versión más resumida en Torre Villar, Ernesto de la: Instrucciones y Memorias de los Virreyes Novohispanos, México, 1991, tomo II, págs. 771-792.

59 Ibídem., fols. 76v-77. 
A través de la visita se sacó también a la luz la existencia de parcialidades dentro de la Audiencia, una de las cuales, llamada "la Sacra Liga", estaba compuesta de españoles y liderada en ese tiempo por el oidor D. Miguel Calderón de la Barca. La otra estaba formada por criollos y a su frente D. Tristán de Rivadeneyra, siendo sustituido en su ausencia por D. Juan de Oliván. Esto servía para beneficiar las causas de cada bando, de tal modo que en el exterior se decía "estar puestos los bolos". No obstante, en "la Sacra Liga" había a veces también criollos, lo que indicaba que no existía una polarización peninsular-criollo, ni era una cuestión de lugar de origen ni de ideología, sino de conveniencias. ${ }^{60}$

También el conde de Frigiliana hacia 1717 había propuesto al Consejo que los sujetos que se nombraran para las Audiencias de Indias fueran españoles, a fin de que se tuviera "cierta evidencia de su literatura, y buenas prendas". ${ }^{61}$

Pese a todas estas opiniones, recogidas en esencia por Ahumada en su manifiesto, en el transcurso del tiempo se había verificado que ninguno de estos argumentos habían sido óbice para que los españoles americanos obtuvieran plazas en los tribunales de justicia u otros empleos seculares o eclesiásticos dentro de la administración indiana. ${ }^{62}$

A nuestro modo de ver, el alegato de Ahumada no hay que magnificarlo, porque no parece responder a un planteamiento ideológico, y por lo tanto no es un testimonio revelador de la nueva conciencia política del criollo. El manifiesto de Ahumada pensamos que, sin olvidar que el siglo XVIII fue una época de revisionismo y progreso en muchos campos, ni tampoco el malestar y descontento secular que pudieron sentir estos últimos, hay que enmarcarlo dentro del episodio de la condena de españoles a obrajes, que

60 AGI, Escribanía de Cámara, 278C. Declaración de D. José de Uribe, de D. Féliz Suárez de Figueroa y de D. Andrés de Lisiaga. México, 16 de noviembre, 14 de diciembre de 1716 y 5 de abril de 1717, en Visita de Garzarón a la Audiencia de México. Cuaderno 2. ${ }^{\circ}$, fols. 186v y 494 y Cuaderno 4. ${ }^{\circ}$, fol. $36 \mathrm{v}$.

61 AGI, Indiferente General, 1293. José Rodrigo a D. Luis Miraval. Segovia, 29 de mayo de 1717. Hace mención de dos consultas del Consejo de Indias y del voto particular del conde de Frigiliana, Burkholder y Chandler: De la impotencia a la autoridad..., pág. 59.

62 Para las plazas dadas a los criollos en diferentes Audiencias destaca la obra de Burkholder y Chandler antes citada. Para la de Lima, la de Lohmann Villena: Los ministros de la Audiencia... Sobre éstos y otros empleos, Tomás y Valiente, Francisco: La venta de oficios en Indias (1492-1606), Madrid, 1972; Navarro García, Luis: "Los oficios vendibles y renunciables en Nueva España durante la guerra de Sucesión" en Anuario de Estudios Americanos, Sevilla, 1975, págs. 133-154; y Sanz Tapia, Ángel: "Aproximación al beneficio de cargos políticos americanos en la primera mitad del siglo XVIII" en Revista Complutense de Historia de América, Madrid, 1998, n. o 24, págs. 147-176. 
nos muestra las alianzas convencionales entre grupos de peninsulares y criollos en defensa de sus intereses, y por el cual se acrecentó la tirantez entre ellos. La anunciada resolución del monarca de que no se le consultase para empleo político o militar a los naturales de Indias vendría a exacerbar aún más los ánimos de Ahumada, y posiblemente de otros criollos que como él pudieran estar a la expectativa de obtener algún puesto en la administración indiana. La supuesta determinación del monarca, inconscientemente, venía a dar la razón a sus rivales, los de "la nación española".

Era, pues, una protesta ante una situación considerada injusta, y que afectaba a la propia estimación e intereses del autor del alegato. Ahumada había nacido en Nueva España y se había formado en un colegio elitista, el de Nuestra Señora de Todos los Santos, en cuyas constituciones y estatutos se exigía que los alumnos fueran "limpios de toda mala raza de indios, mulatos y nuevamente convertidos a nuestra Santa Fe", ${ }^{63}$ y ejercía ahora como letrado en la Audiencia mexicana. Es presumible, por tanto, que aspirase a una plaza en la administración de justicia para luego ir ascendiendo, ${ }^{64}$ y que ante el rumor de la posible resolución del rey viera amargamente frustradas sus lógicas pretensiones. Movido por el malestar que le debió causar esa noticia, pensamos que decidió redactar el escrito utilizando hábilmente un discurso ya conocido. No queremos oscurecer con ello el posible patriotismo de Ahumada, ni la generosa intención de favorecer a sus paisanos ante la anunciada decisión de la Corona, que no sólo le afectaba a él, pero pensamos que aún quedaba mucho camino por recorrer para llegar a una concienciación colectiva del criollo, que daría como resultado la emancipación.

Siguiendo a Lynch y Lohmann Villena, consideramos que sería anacrónico calificar el conjunto de la política española en América y cada una de las respuestas de los americanos como un preámbulo a la independencia,${ }^{65} \mathrm{y}$ un engaño asegurar que la identidad de patria constituía un inflexible principio de unión. ${ }^{66}$

63 AGI, Escribanía de Cámara 207B. El provincial fray José de Noriega a S.M. México, 24 de octubre de 1692. Ver Castañeda Delgado, Paulino: "Evangelización y cultura" en Historia de España, Madrid, 1998, tomo XVIII-2, pág. 636.

64 Burkholder y Chandler: De la impotencia a la autoridad..., pág. 16, exponen los pasos que generalmente solían seguir los "pretendientes".

65 Lynch, John: "El reformismo borbónico en Hispanoamérica” en Guimerá, Agustín (editor): El reformismo borbónico, Madrid, 1996, pág. 57. Otras ideas sobre el criollismo en O’Gorman, Edmundo: Meditaciones sobre el criollismo, México, 1970, pág. 25, en que asevera que el antagonismo entre criollos y gachupines se debía especialmente a la distinta forma de entender la vida novohispana.

66 Lohmann Villena: Los ministros de la Audiencia..., pág. XLVII. 
Resulta curioso, además, que el alegato en una materia de tanto peso como parecía ser ésta, que debería haber levantado una oleada de clamor y que se producía en un momento álgido de fricción entre españoles y americanos, se hiciese en nombre de los criollos pero fuese firmada sólo por dicho abogado.

No menos extraño resulta que, si en el caso que hemos expuesto de la condena de los españoles a obrajes, los tres ministros que dieron la sentencia, es decir, Oliván, Chirinos y de la Veguellina, eran criollos, ¿por qué decían entonces los de la "nación española" —integrada también por criollos—que aquéllos les odiaban? ¿Cuál era la diferencia entre unos criollos y otros en ese tiempo? La respuesta, que viene a dárnosla la "nación española" con unos tintes racistas, no en términos absolutos, sino como excusa para lograr provechos y prerrogativas particulares, dice así:

"En Indias, el nombre español es genérico que toma principio de uno que pasa a ellas donde se desvía, pierde de vista y aún de la memoria su primer origen, según las mezclas de que nace su prole y descendencia que toma los varios nombres que son notorios y con que los distingue la vulgar inteligencia de aquellos naturales de que provienen, que todos o los más, suponen ser españoles fundados en el primer principio de donde derivan, pero en riguroso sentido, no se consideran tales sino los españoles puros y los criollos en que no se halla diferencia en lo común de la población" ${ }^{67}$

¿Quiénes eran los representantes de la "nación española que reside en la ciudad de México y sus vecinos españoles y criollos hasta 242 consortes" ${ }^{68}$ y que tanto defendió el que no se condenara a españoles a obrajes? Según el poder que otorgaron al escribano D. Jacobo Gómez de Paradela, algunos de ellos eran: D. Juan Antonio de Urrutia, marqués de Villar del Aguila; ${ }^{69}$ D. Francisco de Ursúa Munárriz, conde del Fresno de la Fuente, regidor de México; D. Domingo de la Canal, prior que fue del Consulado de México; D. Juan del Castillo, teniente coronel y regidor de esa ciudad; D. Juan de la Peña, alguacil mayor de México y tesorero de la Bula de la Santa Cruzada; D. Juan Gutiérrez Rubín de Celis, capitán y actual asentista del nuevo impuesto del pulque blanco; D. Juan Esteban de Iturbide,

67 AGI, México, 673. Memorial de D. Domingo Pérez de Celis a S.M. Acerca del vocablo "español”, así como el de "criollo", "gachupín”, etc., consultar Alvar, Manuel: Léxico del mestizaje en Hispanoamérica, Madrid, 1987. Arrom, Juan José: Certidumbre de América, Madrid, 1971.

68 AGI, México, 674. Ese era el encabezamiento de algunos de los memoriales, por ejemplo en uno de D. Domingo Pérez de Celis a S.M. (Sin fecha).

69 Un estudio biográfico de este personaje en Ramírez Montes, Guillermina y José Iturrate: Un ilustre ayalés en México. Juan Antonio de Urrutia y Arana.1670-1743, Vitoria, 1979. 
capitán; D. José y D. Pedro de Escorza y Escalante, dueños de obrajes; D. Antonio de las Casas Luna Arellano y Orellana, regidor de México; D. Francisco Antonio Sánchez de Tagle, capitán; D. Gaspar Madrazo y Escalera, ex alcalde ordinario y electo corregidor de México, etc., y otros representantes de la ciudad y especialmente del comercio, que hacían un número de 242 personas. $^{70}$

No obstante, en opinión de la Sala del Crimen, fue el escribano D. Jacobo Gómez Paradela quien, con poder que le dieron algunos de los citados anteriormente, solicitó, pidió y recogió las firmas "ostiatim", o lo que es lo mismo, de puerta en puerta, en las casas, tiendas y tabernas de montañeses y otros, para lograr sus fines. De lo que se deduce que muchos de los que firmaron el poder ni eran nobles ni gente de alta distinción, como los que aparecían a la cabeza del poder, sino mercaderes, vinateros, tenderos y dependientes de los priores del Consulado. ${ }^{71}$

Comentaban los tres ministros de la Sala del Crimen que, según estudios del geógrafo Nicolás de Fer, autor del entonces moderno "Atlas curioso", había sólo en México más de treinta mil españoles que hacían un total aproximado de cien mil vecinos, y que cómo entonces se podían atribuir únicamente 200 hombres el arbitrio de decidir por todos. Añadían que algunos de aquéllos, que cuando pobres eran moderados, ahora que eran ricos no cabían en el círculo de esa América, en especial los asentistas del pulque y del alumbre, que tenían a sus órdenes muchos sirvientes y eran capaces por ello de conmover y turbar el reino.

Aducían los de la Sala la informalidad del poder que dieron a D. Jacobo Gómez, porque éste puso en el escrito los nombres al montón, ya que no sabía quiénes iban a firmar o no al pie de ese poder. Tampoco se precisaba con qué fines se había dado, en qué casa se juntaron los otorgantes, quiénes fueron los asistentes, qué puntos se tuvieron en cuenta para confeccionarlo, etc., lo cual acreditaría que era voluntad de todos el hacer aquel acto. ${ }^{72}$

El asunto de la condena de los dos montañeses a obrajes vino a demostrar, como ya hemos referido, que lo que subyacía entre los de la Sala y "la nación española" no era más que la rencilla entre dos bandos por la defensa de intereses y privilegios. D. Juan de Oliván Rebolledo, especialmente, y D. Nicolás Chirinos Vandeval y D. Juan de la Veguellina Sandoval, los tres

70 AGI, México, 673. Certificación de D. Jacobo Gómez de Paradela. México, 21 de octubre de 1721 .

71 AGI, México, 673. La Sala del Crimen a S.M. México, 10 de abril de 1721.

72 Ibídem. 
criollos, "dueños" de la Sala del Crimen por la falta de personal, intentaron bajarle "los humos" a los que se hacían llamar "la nación española", y que dicha pena se aplicara a los delincuentes que la mereciesen, independientemente de su lugar de nacimiento y clase social, sin descartar que pudiera pesar también en esta sentencia alguna venganza personal. "La nación española", por su parte, utilizó la sentencia de la Sala para que no se generalizara una condena que pudiera afectarles a ellos o a sus allegados en algún momento, y tal vez para quitar de en medio a aquellos letrados que parecían no favorecer sus intereses.

Las rencillas entre Oliván y D. Juan Rubín de Celis y D. Pedro de Escorza (los dos que promovieron que se hiciera el referido poder) eran públicas, no sólo en asuntos profesionales sino personales. Por ejemplo, con D. Juan Rubín de Celis, porque siendo Oliván juez de almonedas, se resistió — según su apoderado Ahumada — a que se le rematase el ramo del pulque seis meses antes de cumplirse el remate anterior y por nueve años como pretendía Rubín de Celis, cuando por reales cédulas estaba dispuesto que fuera por cinco. ${ }^{73}$ En versión de "la nación española" era Oliván el que estaba resentido y agraviado con Rubín de Celis porque éste, teniendo a cargo la renta del pulque blanco y conocedor de que un cuñado de Oliván llamado D. Juan Rodezno fabricaba aguardiente prohibido en distintos parajes, que administraba públicamente el receptor D. Diego Ignacio de la Rocha, lo puso en conocimiento del virrey.

Algo similar ocurrió entre Oliván y D. Pedro de Escorza. Según "la nación española", el primero había puesto todo su empeño para que a Rodezno, su cuñado, se le adjudicara el asiento de los alumbres, pero el remate final fue para D. Pedro de Escorza, por lo cual le tenía un gran rencor. También hubo sus roces en un pleito que Escorza tenía y que, según Ahumada, no obtuvo el sufragio de Oliván, y desde entonces le estaba preparando asechanzas. Sin embargo, en opinión de "la nación española", como Oliván no pudo desahogar con ellos su resentimiento lo hizo con los dos montañeses. ${ }^{74}$

Según parece, esas desavenencias iban más allá de lo puramente profesional. En opinión de un testigo que había escuchado unos comentarios a D. José de Escorza, del grupo de "la nación española", éstos habían enviado "correos a capa" a Zacatecas amenazando al que iba a ser suegro de Oliván (Campa) ${ }^{75}$ para que no le diera a su hija. Al parecer, aquéllos tenían

73 AGI, México, 674. Memorial de D. Juan Antonio de Ahumada (Sin fecha).

74 AGI, México, 673. Ibídem. Memorial de D. Domingo Pérez de Celis a S.M. (Sin fecha).

75 Parece ser que este sujeto era D. Fernando de la Campa, conde de San Mateo de Valparaíso. 
intención no sólo de frustrar la boda de Oliván, sino de que la hija de Campa se casara con uno de los dos montañeses sentenciados, para cuyo efecto "la nación" le iba a dotar con cien mil pesos. ${ }^{76}$

La Sala del Crimen afirmaba que el fin de todo el alboroto promovido por aquéllos no era la piedad hacia los montañeses, sino la ojeriza que le tenían a los ministros porque administraban la justicia sin favoritismos, y no al contrario como los otros pretendían. En opinión de la Sala, la prueba estaba en que tanto que alardearon en la defensa de los dos reos, ni les ofrecieron el dinero para pagar el robo y de ese modo evitar que fueran a obrajes, ni limosna alguna, ni siquiera les fueron a visitar a la cárcel. En cambio, y según divulgó la propia "nación española", habían enviado a sus apoderados en Madrid treinta y dos mil pesos con instrucciones secretas para tratar de conseguir quitarles las plazas a los ministros. ${ }^{77}$

Acerca del exagerado revuelo auspiciado por "la nación española" por la sentencia de la Sala decía D. Juan Antonio de Ahumada, el apoderado de Oliván en Madrid, que era absurdo el que pudiera pensarse que por el hecho de condenar a dos ladrones, que además eran vagabundos y estaban amancebados, quedara deshonrada una nación tan ilustre como la española. ${ }^{78}$ Se da la circunstancia de que por este tiempo Ahumada fue encarcelado por orden del monarca; posiblemente se debiera a que se presentó en la Corte sin licencia, según parece desprenderse de un memorial que dirigió al rey. ${ }^{79}$

Posteriormente, aunque no consiguió Ahumada un puesto en los tribunales de justicia de Nueva España, obtuvo el de corregidor de Zacatecas por cinco años y con un salario de mil pesos, en atención al servicio que hizo de noventa mil reales de vellón entregados en la Tesorería General "para las urgencias presentes". El juramento lo hizo en Madrid el 7 de abril de 1729 ante D. Antonio de Salazar y Castillo, y se le dio licencia para llevar a Nueva España a un criado y doce cajones de libros para su ministe-

76 AGI, México, 673. Declaración de D. Alonso de Adán, español, comisario conductor de colleras a obrajes de Querétaro. México, 27 de octubre de 1721, en Testimonio n. ${ }^{\circ} 17$ de la averiguación hecha por la Sala del Crimen sobre españoles asalariados en los obrajes. México, 30 de octubre de 1721, fols. 4-4v. Este testigo hace alusión a D. ${ }^{a}$ Juliana de la Campa y Cos, que luego sería la segunda esposa de Oliván. Burkholder y Chandler: Biographical Dictionary..., pág. 241.

77 AGI, México, 673. La Sala del Crimen a S.M. México, 10 de abril y 3 de noviembre de 1721.

78 AGI, México, 674. Memorial de D. Juan Antonio de Ahumada a S.M. (Sin fecha).

79 AGI, México, 674. Otro Memorial de D. Juan Antonio de Ahumada a S.M. (Sin fecha). D. Juan Rubín de Celis y varios coaligados montañeses esparcieron por México la noticia de que a consulta del Consejo se trataba de castigar a Oliván. 
rio ${ }^{80}$ La toma de posesión tuvo lugar en el Ayuntamiento de Zacatecas el 11 de julio de 1731 ante el teniente general de corregidor D. Pedro José Bernardes y los capitulares. ${ }^{81}$

En 1732 se le hizo merced de dicho corregimiento a D. Tomás Domingo de Figueroa en atención a sus servicios y al de seis mil pesos de a diez reales de plata, con la condición de que si no pudiera por algún motivo tomar posesión de él lo hiciera D. Gregorio de Mendoza o D. Juan Antonio de Ahumada. ${ }^{82}$ Figueroa tomaría posesión en $1736{ }^{83}$

\section{¿Anticriollismo del rey?}

Los del Consejo de Indias - que en ese tiempo estaba presidido por el que hacía poco fuera virrey de Nueva España, marqués de Valero ${ }^{84}$ expusieron al monarca de nuevo los perjuicios que podrían seguirse de que Oliván continuara ocupando su plaza en México, porque se podía prever, con los émulos que tenía ocasionados de la referida causa, el que intentasen alguna venganza en perjuicio de aquellos vecinos y quietud del Reino. Así pues, le seguían proponiendo al rey que removiese a Oliván a la Audiencia de Lima, ya que para el más exacto cumplimiento de la obligación de los ministros, y siempre que había convenido al servicio del rey, se había practicado el trasladarlos de unas audiencias a otras. De esta manera pasaría Oliván a una audiencia que tenía más salario y podía conservar su antigüedad, como estaba prevenido por las leyes para estos casos, y como se hacía en las Chancillerías de Valladolid y de Granada. ${ }^{85}$

80 AGI, Guadalajara, 130. Real cédula a Andrés de Elcorobarrutia. Jaraycejo, 12 de enero de 1729. AGI, Contratación, 5477, N. 156, imágenes 3-3v. Real título. Isla de León, 29 de marzo de 1729. Hacen mención de la merced del corregimiento a Ahumada, López Cámara: La génesis de la conciencia liberal..., pág. 297 (cita a su vez a Beristaín de Souza: Biblioteca Hispanoamericana..., pág. 33). Burkholder y Chandler: De la impotencia a la autoridad..., pág. 68 (AGI, Indiferente General, 1847. Relación que se ha formado de orden de S.M. comunicada por el marqués de la Ensenada. Madrid, 1 de junio de 1746).

81 AGI, Guadalajara, 130. Testimonio de la toma de posesión de D. Juan Antonio de Ahumada. Zacatecas, 26 de marzo de 1732. El corregidor propietario, D. José Raimundo de la Puebla Barreda, estaba ausente.

82 AGI, Guadalajara, 130. Real título. Sevilla, 11 de mayo de 1732.

83 AGI, Guadalajara, 111. D. Tomás Domingo de Figueroa a S.M. Zacatecas, 10 de abril de 1736.

84 El marqués de Valero fue presidente del Consejo de Indias desde el 28 de enero de 1724, y murió el 29 de noviembre de 1727. Gildas, Bernard: Le Secrétariat d'etat et le Conseil espagnol des Indes (1700-1808), Genéve, 1972, pág. 211.

85 AGI, México, 674. Consejo de Indias a S.M. Madrid, 31 de octubre de 1726. 
Uno de los ministros del Consejo de Indias, D. Gonzalo Ramírez de Vaquedano, estimó que sería de muy mal ejemplo el separar a Oliván de la Audiencia de México, porque había sido ministro de la misma durante catorce años, con buena fama y dispensación de su naturaleza. Recordó que en la visita de Garzarón quedó libre por su recto proceder, el cual había demostrado también en las comisiones que los virreyes le asignaron. ${ }^{86}$ Alegaba Vaquedano que si se trasladaba a Oliván, los hombres ricos de México tendrían motivos para amedrentar a los ministros togados siempre que no se avinieran a sus deseos. Hacía presente lo importante que era el que quedase intacta la autoridad de los ministros para que así se respetaran sus decisiones. Finalmente añadía que ya había cesado la causa que ocasionó la queja de los montañeses, pues los reos habían admitido la condena y estaban cumpliéndola y que, en su opinión y a la vista de los autos, el asunto le pareció una porfía contra Oliván.

También otro de los ministros del Consejo, D. Manuel Silva Ribera, marqués de Montemayor, era del criterio de que a Oliván se le mantuviera en México, por la molestia que se le seguiría de trasladarlo a la de Lima, y por su demostrada honestidad profesional. ${ }^{87}$

La resolución del monarca en este asunto fue la de conformarse con el dictamen de Ramírez de Vaquedano, y a la vez mandó algo que como ya hemos expuesto se rumoreaba, y que en este momento se consolidó:

"la Cámara esté a la mira de que para los empleos de Indias no se elijan o propongan naturales de aquellos Reinos". ${ }^{88}$

Esta resolución del monarca causó sus dudas en la Secretaría del Consejo, porque no sabían si, según dicho dictamen, se deberían comprender en general los empleos de gobernadores, oficiales reales, alcaldes

86 Ibídem. Aluden los del Consejo a varios testimonios presentados por Ahumada en los que se reconocía la confianza que los virreyes Linares y Valero habían depositado en Oliván. Entre otras cosas se le había encargado el exterminio del aguardiente y bebidas prohibidas y la vigilancia del juego de gallos. Se destacaba su aplicación en desterrar a los vagabundos y ociosos con providencias para su castigo, siendo una de ellas la de que se condenaran a obrajes. Había servido los empleos de gobernador de la Provincia de Texas y desde 1719 desempeñaba el cargo de auditor de Guerra de Nueva España. Véase también Navarro García, Luis: Don José de Gálvez y la Comandancia General de las Provincias Internas del Norte de Nueva España. Sevilla, 1964, págs. 64,75,80 y 526. Burkholder y Chandler: Biographical Dictionary, págs. 240-241.

87 AGI, México, 674. Consejo de Indias a S.M. Madrid, 31 de octubre de 1726.

88 Ibídem. AGI, México, 674. Al dorso de este documento está la resolución del rey. En Consejo, 8 de agosto de 1727, se dijo "Publíquese este día y se tenga presente lo resuelto por S.M. en la Cámara, y para este fin se dé el aviso correspondiente a la Secretaría del Perú". 
mayores, corregidores, castellanos y otros semejantes, o estaba limitado solamente a los ministros de las Audiencias, como lo disponían las leyes y el Decreto de 31 de marzo de 1720.

La respuesta del fiscal del Consejo fue la de que por el citado decreto se hacía referencia expresa a las plazas de administración de justicia y, aunque ahora, en la última resolución, se comprendían indistintamente los empleos de Indias, en su opinión, se debía entender sólo para los que tenían el cargo de la administración de justicia y que, si pareciera, se le podría comentar al rey para que aclarase esta duda. ${ }^{89}$

A la Cámara no le pareció necesario consultar al monarca como apuntaba el fiscal, pues determinó que en la resolución de S.M. únicamente se debían comprender las plazas de las Audiencias que tenían la administración de justicia y no los demás empleos..$^{90}$

Está claro que la voluntad del monarca no respondía a una animosidad hacia los criollos, sino a la de hacer frente a una situación que, como hemos visto, se hacía insostenible, a pesar de que con la visita de Garzarón a la Audiencia se habían destituido a muchos ministros por sus excesos, la mayoría criollos. La determinación real vino no sólo a confirmar las leyes dadas a este fin y el decreto de 31 de marzo de 1720, sino a ampliarla porque se hablaba de "empleos" en general sin especificar cuáles, aunque luego no se llevara a efecto con todo su rigor por sugerencia primero del fiscal del Consejo y por decisión después de la Cámara, que le dieron la misma interpretación que al real decreto de 31 de marzo de 1720. De este modo se pretendía evitar las redes de parentesco y de poder que tanto perjudicaban a la recta administración de justicia.

En verdad, esta situación la había provocado la propia Corona con la venta de oficios ${ }^{91}$ para hacer frente a los gastos de la Corte y las frecuentes guerras. Esto y las repetidas dispensaciones de leyes, tanto a los españoles como a los americanos, fueron creando un entramado de poder político, administrativo y económico que propició los enfrentamientos entre unos y otros. Lo que trataba el rey ahora era de recuperar el control de las Audiencias, en un periodo analizado por Burkholder y Chandler y que tan acertadamente han calificado como "la edad de la impotencia". ${ }^{2}$

89 AGI, México, 674. Nota de la Secretaría. (Sin fecha). Cámara, 18 de agosto de 1727. Respuesta del fiscal. Madrid, 26 de agosto de 1727.

90 AGI, México, 674. Cámara, 27 de agosto de 1727.

91 Hay numerosa bibliografía sobre este tema, entre las obras más representativas están las ya citadas en la nota 62 .

92 Burkholder y Chandler: De la impotencia a la autoridad..., págs. 29-118. 
El control de las Audiencias no era factible a corto plazo: por los compromisos adquiridos por la Corona con los compradores de los oficios y la imposibilidad de devolver a los pretendientes las cantidades entregadas, debido al casi permanente déficit de la Real Hacienda. Así pues, la propia Corona se veía incapaz de salir de esa urdimbre que ella misma había entretejido. Sería a partir de 1750 cuando lograría ir recuperando el control de las Audiencias indianas. ${ }^{93}$

En resumidas cuentas, el asunto de la condena de españoles a obrajes fue utilizado por los diversos grupos, bajo diferentes banderas y como excusa, para defender sus intereses particulares, y por la Corona para paliar los problemas engendrados por el sistema de la venta de oficios.

93 Ibídem, págs. 119 ss. 